\title{
Dihydropyridine Receptor Gene Expression Is Regulated by Inhibitors of Myogenesis and Is Relatively Insensitive to Denervation
}

\author{
Hue-Teh Shih, ${ }^{*}$ Mark S. Wathen, ${ }^{*}$ Hélène Bigo Marshall, ${ }^{*}$ John M. Caffrey, ${ }^{\ddagger}$ and Michael D. Schneider ${ }^{\star \neq \$}$ \\ ${ }^{*}$ Molecular Cardiology Unit, Departments of ${ }^{*}$ Medicine, ${ }^{\ddagger}$ Physiology and Molecular Biophysics, and \\ ${ }^{\S}$ Cell Biology, Baylor College of Medicine, Houston, Texas 77030
}

\begin{abstract}
To evaluate developmental and physiological signals that may influence expression of the dihydropyridine-sensitive "slow" $\mathrm{Ca}^{2+}$ channel, we analyzed dihydropyridine receptor (DHPR) mRNA abundance in mouse skeletal muscle. Using synthetic oligonucleotide probes corresponding to the rabbit skeletal muscle DHPR, a $6.5 \mathrm{~kb}$ DHPR transcript was identified in postnatal skeletal muscle and differentiated $\mathrm{C} 2$ or $\mathrm{BC}_{3} \mathrm{H1}$ myocytes, but not cardiac muscle or brain. DHPR gene expression was reversibly suppressed by $0.4 \mathrm{nM}$ transforming growth factor $\boldsymbol{\beta - 1}$ or by transfection with a mutant $\mathrm{c}-\mathrm{H}$-ras allele, nominal inhibitors of myogenesis that block the appearance of slow channels and DHPR. In contrast, both $\mathrm{BC}_{3} \mathrm{H1}$ and $\mathrm{C} 2$ myocytes containing the activated ras vector expressed the gene encoding the nicotinic acetylcholine receptor $\delta$ subunit, demonstrating that not all muscle-specific genes are extinguished by ras. Denervation stimulated DHPR gene expression less than 0.6-fold, despite 8-fold upregulation of $\delta$-subunit mRNA and reciprocal effects on the skeletal and cardiac $\alpha$ actin genes. Thus, DHPR gene induction is prevented by inhibitors of other muscle-specific genes, whereas, at most, relatively small changes in DHPR mRNA abundance occur during adaptation to denervation. ( $J$. Clin. Invest. 1990. 85:781-789.) calcium channels $\bullet$ differentiation $\bullet$ MyoD1 $\bullet$ oncogenes $\bullet$ skeletal muscle $\bullet$ transforming growth factor $\beta-1$
\end{abstract}

\section{Introduction}

The exact molecular mechanisms that might control the expression of calcium channels during muscle ontogeny and adaptation are presently not understood. For example, the density of dihydropyridine (DHP) ${ }^{1}$-sensitive $\mathrm{Ca}^{2+}$ channels is sub-

A preliminary report of this research was presented at the Annual Meeting of the American Federation for Clinical Research, Washington, DC, May 1989, and has been published in abstract form (1989. Clin. Res. 37:296a).

Address reprint requests to Dr. Michael D. Schneider, Molecular Cardiology Unit, Baylor College of Medicine, One Baylor Plaza, Room 506C, Houston, TX 77030. Dr. Caffrey's current address is Department of Neurology, Yale University School of Medicine, Veterans Administration Medical Center, Room 157A, West Haven, CT 06510.

Received for publication 19 June 1989 and in revised form 24 October 1989.

1. Abbreviations used in this paper: DHP, dihydropyridine; DHPR, dihydropyridine receptor; gad, glyceraldehyde-3-phosphate dehydrogenase; $m c k$, muscle creatine kinase; $\mathrm{nAchR} \delta$, delta subunit of the nicotinic acetylcholine receptor; TGF $\beta 1$, type $\beta-1$ transforming growth factor.

J. Clin. Invest.

(C) The American Society for Clinical Investigation, Inc. 0021-9738/90/03/0781/09 \$2.00

Volume 85, March 1990, 781-789 ject to homologous and heterologous regulation by DHPs and $\beta$-adrenergic ligands (1), may respond to membrane potential (2) or calcium itself (3), and might be altered in cardiomyopathies of animals (4) and man (5). Purification of the DHP receptor (DHPR) from transverse tubules of rabbit skeletal muscle (e.g., 6) and isolation of the corresponding cDNA $(7,8)$ have made $\mathrm{Ca}^{2+}$ channel gene expression accessible to molecular analysis, at least in skeletal muscle. The $\alpha_{1}$-subunit protein contains the receptor site for both DHP derivatives and phenylalkylamines (6) and possesses structural similarity to voltage-gated $\mathrm{Na}^{+}$and $\mathrm{K}^{+}$channels $(7,9)$. The inference that the DHP-binding polypeptide might function as the voltage-sensing component of the proposed $\mathrm{Ca}^{2+}$ channel complex is strongly supported by the demonstration that DHPR cDNA restores both "slow" current and excitation-contraction coupling in cultured skeletal muscle cells from mice with the lethal mutation, muscular dysgenesis (10). A DHPR $\alpha_{1}$ expression vector also is sufficient to produce voltage-gated, DHP-sensitive $\mathrm{Ca}^{2+}$ currents in murine $\mathrm{L}$ cells, which lack endogenous $\alpha_{2}$, as well as $\alpha_{1}$, subunits (11).

Studies to elucidate the molecular genetics of $\mathrm{Ca}^{2+}$ channel expression would be facilitated by model systems whose biochemical and biophysical differentiation can be precisely regulated. We have previously analyzed the DHP-sensitive $\mathrm{Ca}^{2+}$ channels formed in differentiating $\mathrm{C} 2$ and $\mathrm{BC}_{3} \mathrm{H} 1$ muscle cells (12-14), whose slow kinetics of activation and DHP-binding properties correspond to those of skeletal muscle and are distinct from those found in neurons, smooth muscle, or cardiac muscle cells. Neither cell line expressed functional $\mathrm{Ca}^{2+}$ channels during proliferative growth, and the appearance of slow current was dependent on removal or depletion of serum growth factors $(12,14)$. Conversely, $\mathrm{Ca}^{2+}$ channel formation could be prevented by transforming growth factor $\beta 1$ (TGF $\beta 1$ ), a peptide inhibitor of muscle differentiation (14-16). Equivalent results were produced by transfection with an activated allele of the H-ras proto-oncogene (12), encoding a guanine nucleotide binding protein that is postulated to mediate certain growth factor effects $(12,17-21)$. Like the induction of slow channels assayed by whole-cell clamp techniques, formation of DHP receptor sites was contingent on serum withdrawal, and was suppressed both by ras and by TGF $\beta 1$ (13).

These findings suggested that the ontogeny of $\mathrm{Ca}^{2+}$ channels during myogenesis may involve intracellular events similar to those that control formation of other muscle-specific gene products $(20,22)$. However, a number of issues were still unresolved. First, the synthesis of a functional ion channel might involve control at diverse levels. Subunit assembly, glycosylation, translational control, and alternative mRNA splicing each have been implicated as potential regulatory steps in ion channel formation (23-25), in addition to control at the level of gene transcription. Second, the inference remains open to question, that growth factors and oncogenes would neces- 
sarily suppress $\mathrm{Ca}^{2+}$ channel formation through a block to the induction of all muscle-specific genes. Finally, a variety of physiological signals including innervation and muscle activity stimulate dramatically the genes encoding other ion channels (e.g., 26-28), whereas the available physiological data suggest that denervation of mammalian skeletal muscle exerts at most a very modest effect on slow $\mathrm{Ca}^{2+}$ current $(29 ;$ cf. 30$)$ and asymmetric charge movement, the postulated gating current for $\mathrm{Ca}^{2+}$ release (31). Together, these observations indicate that DHPR gene expression might possess regulatory features both in common with and distinct from other ion channels in skeletal muscle.

As a first step toward understanding the molecular events that determine $\mathrm{Ca}^{2+}$ channel expression, we have investigated DHPR gene expression during myogenesis, both in vivo and in vitro. The present study was designed to ascertain whether DHPR gene expression in mouse skeletal muscle is tissue-specific and developmentally regulated. $\mathrm{C} 2$ and $\mathrm{BC}_{3} \mathrm{H} 1$ muscle cells were analyzed to test the prediction that growth factors and oncogenes affect the expression of functional DHP-sensitive $\mathrm{Ca}^{2+}$ channels through a block to induction of the DHP receptor gene, and to establish whether all muscle-specific genes necessarily are suppressed by nominal inhibitors of the myogenic pathway. Finally, experiments were undertaken to examine the possible control of DHPR gene expression by denervation.

\section{Methods}

Northern blot hybridization. Total cellular RNA was size-fractionated by formaldehyde-agarose gel electrophoresis and transferred to nylon membranes (32-34). To identify putative DHP receptor transcripts, oligonucleotide probes were synthesized, complementary to nucleotides 1-60 and 4090-4131 of the DHP receptor cDNA isolated from transverse tubules of rabbit skeletal muscle (7). Hybridization of DHPR probes was performed at $42^{\circ} \mathrm{C}$ in $5 \times \mathrm{SSC} / 5 \times$ Denhardt's solution $/ 5 \% \mathrm{NaDodSO}_{4} / 50 \%$ formamide $/ 100 \mu \mathrm{g} \cdot \mathrm{ml}^{-1}$ salmon sperm DNA; blots were washed twice in $3 \times \mathrm{SSPE} / 1 \% \mathrm{NaDodSO}_{4}$ at $50^{\circ} \mathrm{C}$ for $15 \mathrm{~min}$, then in $1 \times \mathrm{SSPE} / 1 \% \mathrm{NaDodSO}_{4}$ at $50^{\circ} \mathrm{C}$. The $\alpha$-skeletal and $\alpha$-cardiac actin oligonucleotide probes were complementary to specific $3^{\prime}$ untranslated portions of the corresponding cDNAs $(35,36)$. The $\delta$ subunit of the nicotinic acetylcholine receptor $(\mathrm{nAchR} \delta)$ was analyzed using a 20-mer complementary to the 3 '-untranslated nucleotides 1842-1861 of the murine sequence (37). Muscle creatine kinase ( $m c k$ ) mRNA was measured using the 0.88-kbp Pst I fragment of pHMCKIa (38). Expression of MyoD1, which becomes activated as an early event in the myogenic pathway and confers the muscle phenotype to certain non-muscle cells, was examined using nucleotides 580-639 of the myc homology domain (39). Oligonucleotide probes were end-labeled using T4 polynucleotide kinase, and cDNA restriction fragments were labeled by the random primer method (40). Blots were exposed to Kodak $\mathrm{XAR}-2$ film at $-70^{\circ} \mathrm{C}$ with intensifying screens and were quantitated by scanning densitometry.

Denervation. Denervation was performed on 11-12-wk-old C3H mice under general anesthesia with intramuscular ketamine (ParkeDavis Co., Morris Plains, NJ)/xylazine (Haver, Shawnee, KS)/acepromazine (Techamerica, Kansas City, MO). Segments of the sciatic nerve and proximal segments of the left tibial and peroneal nerves (1-2 $\mathrm{mm}$ ) were excised at their bifurcation. Left hindlimb soleus and flexor digitorum longus muscles were collected at intervals after denervation, and the contralateral muscles served as controls.

Cell culture. Undifferentiated C2 cells (41) were maintained in Ham's medium F12 containing 20\% fetal bovine serum (14). At $85 \%$ confluency, differentiation was induced in Dulbecco's modified Eagle's medium containing $2 \%$ horse serum. To induce differentiation of $\mathrm{BC}_{3} \mathrm{H} 1$ muscle cells (42), cells were fed medium with fetal bovine serum reduced from $20 \%$ to $0.5 \%(12,18,43)$. All media were purchased from Gibco Laboratories (Grand Island, NY), and sera were obtained from Hyclone, (Logan, UT). Oncogene-transfected $\mathrm{BC}_{3} \mathrm{H} 1$ cell lines (cotransfected with the neomycin phosphotransferase as a dominant selectable marker) were thawed from low-passage stocks of clonal isolates described previously $(12,18,43)$ and were maintained in medium containing $400 \mu \mathrm{g} \cdot \mathrm{ml}^{-1} \mathrm{G} 418$. Clonal, ras-transfected C2 cells were a gift from Dr. Eric Olson (19). The homodimeric form of TGF $\beta 1$ isolated from porcine platelets was obtained from R\&D Systems (Minneapolis, MN). (-)S Bay K 8644 (R5417), (+)R Bay K 8644 (R4407), and nifedipine were provided by Dr. Alexander Scriabine (Miles Laboratories, West Haven, CT).

\section{Results}

Dihydropyridine receptor gene expression is tissue-specific and developmentally regulated in vivo. To establish whether formation of the DHP-sensitive slow $\mathrm{Ca}^{2+}$ channel in skeletal muscle is regulated through control at a pretranslational level, DHPR mRNA abundance was analyzed by Northern hybridization, using synthetic oligonucleotides derived from the $\alpha_{1}$ subunit of the rabbit skeletal muscle DHPR cDNA $(7,8)$. Our best results were obtained with the two oligonucleotides reported here, a 60 -mer directed against the $5^{\prime}$-most portion of the coding sequence, and with a 42-mer corresponding to the S6 $\alpha$-helix in domain 4. As shown in Fig. 1, using $15 \mu \mathrm{g}$ of total cellular RNA per lane, a $6.5-\mathrm{kb}$ putative DHPR $\alpha_{1}$ transcript was identified in postnatal $\mathrm{C} 3 \mathrm{H}$ mouse skeletal muscle, in agreement with the size of the transcript reported in rabbit muscle $(7,8)$. DHPR mRNA was detected even at $2 \mathrm{~d}$, in agreement with the existence of functional slow channels in newborn mice (29), and its abundance increased 18 -fold by 2 mo of age. Fast skeletal muscle (latissimus dorsi) expressed $\sim 1.8$-fold more DHP receptor mRNA than slow skeletal muscle (soleus), as might be anticipated on the basis of the greater T-tubular volume, slow current density, and DHP binding in fast muscle $(44,45)$. The probes were specific for skeletal muscle. Little or no binding was seen in mouse heart or brain, using either total RNA (Fig. 1) or polyadenylated RNA (Fig. 2). Equivalent results were obtained with either probe. This result agrees with other evidence that structural differences distinguish the DHP-sensitive $\mathrm{Ca}^{2+}$ channels in skeletal muscle from those in brain or ventricular muscle (47, 48 ), as suggested by the known disparities in channel kinetics and DHP affinity.

$D H P$ receptor $m R N A$ and protein are induced as late events during myogenic differentiation. Neither specific DHP binding sites (Fig. 3) nor DHPR mRNA (Fig. 4) was detected in proliferating $C 2$ cells, which lack functional slow channels (14). Whereas expression of other muscle-specific genes ( $m c k, \alpha-$ cardiac actin, $\alpha$-skeletal actin) was detected within $24 \mathrm{~h}$ or less of serum withdrawal, DHPR mRNA (like DHP receptor sites) first appeared after $2 \mathrm{~d}$, in agreement with the absence of DHP-sensitive current at earlier timepoints; both "transient" $\mathrm{Ca}^{2+}$ channels and sodium channels also are induced in $\mathrm{C} 2$ cells one day or more before slow $\mathrm{Ca}^{2+}$ channels are found (14). DHPR mRNA was induced at least 10 -fold after serum withdrawal. The abundance of DHPR mRNA $72 \mathrm{~h}$ after serum withdrawal was greater than in mouse skeletal muscle 2 $\mathrm{d}$ after birth, but less than that found in vivo at 7 or more days. At 2 and $3 \mathrm{~d}$ of serum withdrawal, Scatchard transformation of saturation analysis identified a single class of noninteracting 


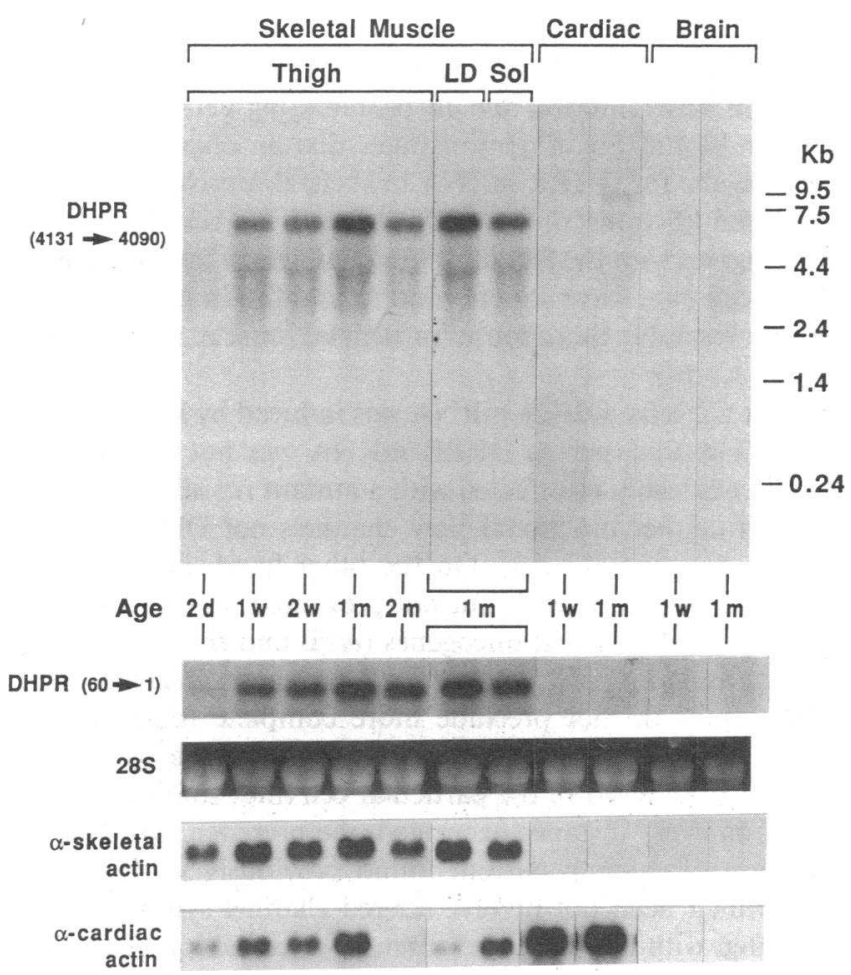

Figure 1. DHPR gene expression is tissue-specific and developmentally regulated in vivo. Total cellular RNA $\left(15 \mu \mathrm{g} \cdot \operatorname{lane}^{-1}\right)$ was isolated from $\mathrm{C} 3 \mathrm{H}$ mouse tissues at the ages shown, and was analyzed by Northern blot hybridization, using the probes indicated at the left of the figure. The specificity and developmental regulation of actin sequences utilized in the subsequent experiments is shown at the bottom of the figure. The specific activities and exposure times for autoradiography differed, and the hybridization signal intensities are not intended to represent the relative abundance of the respective transcripts. A nonspecific hybridization signal at $4.0 \mathrm{~kb}$ associated with the leading edge of $28 \mathrm{~S}$ ribosomal RNA also was seen with oligonucleotides directed against other transcripts. 28S ribosomal RNA is shown for comparison. LD, latissimus dorsi; Sol, soleus.

receptor sites with dissociation constants of 255 and $271 \mathrm{pM}$, and binding site densities of 117 and $375 \mathrm{fmol} \cdot \mathrm{mg} \mathrm{prot}^{-1}$, respectively. These results are similar to the corresponding values for differentiated $\mathrm{BC}_{3} \mathrm{H} 1$ cells $(256 \mathrm{pM}$ and 322 $\mathrm{fmol} \cdot \mathrm{mg} \mathrm{prot}^{-1}$; 13) and contrast with the disparity between ion channel sub-unit mRNA and binding site formation in other systems $(23,25)$.

$T G F \beta 1$ and an activated ras oncogene each prevent the formation of functional slow $\mathrm{Ca}^{2+}$ channels through a pretranslational mechanism. When TGF $\beta 1$ was added to $\mathrm{C} 2$ cells at $400 \mathrm{pM}$ at the time of serum withdrawal, DHPR gene expres-

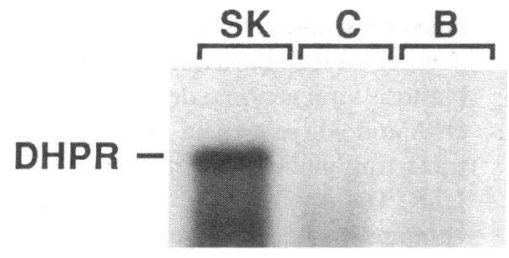

Figure 2. Distribution of the DHPR transcript. Polyadenylated RNA (ref. 46; $5 \mu \mathrm{g} \cdot$ lane $^{-1}$ ) was analyzed by Northern blot hybridization. In this and the subsequent figures, the 42 -

mer complementary to nucleotides $4131-4090$ was used as the DHPR hybridization probe. SK, skeletal muscle; C, cardiac muscle; B, brain.

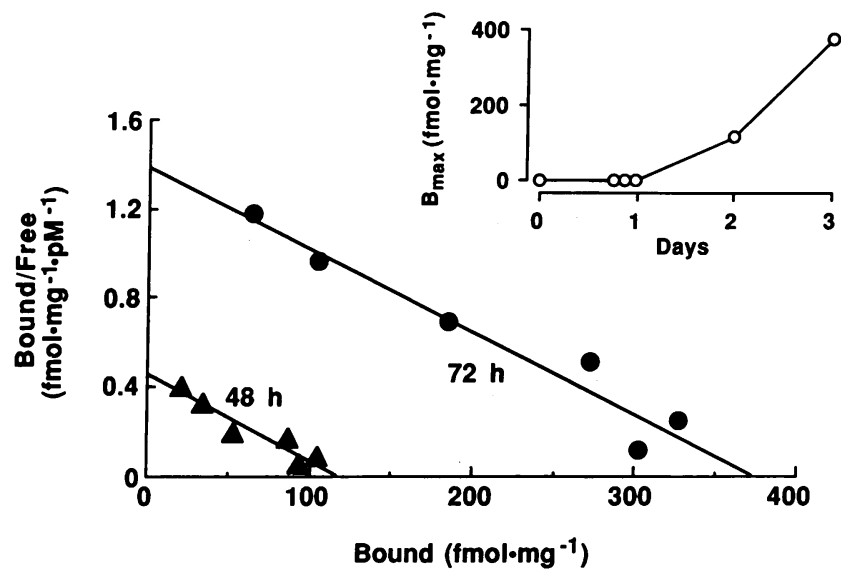

Figure 3. Development of $\left[{ }^{3} \mathrm{H}\right] \mathrm{PN} 200-110$ receptor sites in $\mathrm{C} 2$ muscle cells. $\mathrm{C} 2$ muscle cells were subjected to hypotonic lysis, homogenized, and analyzed for equilibrium binding of $\left[{ }^{3} \mathrm{H}\right] \mathrm{PN} 200-110$ as previously described (14). Scatchard transformation of saturation analysis is shown for $\mathrm{C} 2$ muscle cell membranes 48 and $72 \mathrm{~h}$ after mitogen withdrawal. Binding site density increased from 117 to 375 $\mathrm{fmol} \cdot \mathrm{mg} \mathrm{prot}^{-1}$, with little or no change in $K_{\mathrm{d}}(255$ and $271 \mathrm{pM})$. (Inset) $\left.{ }^{3} \mathrm{H}\right] \mathrm{PN} 200-110$ binding site density in $\mathrm{C} 2$ muscle cells after mitogen withdrawal.

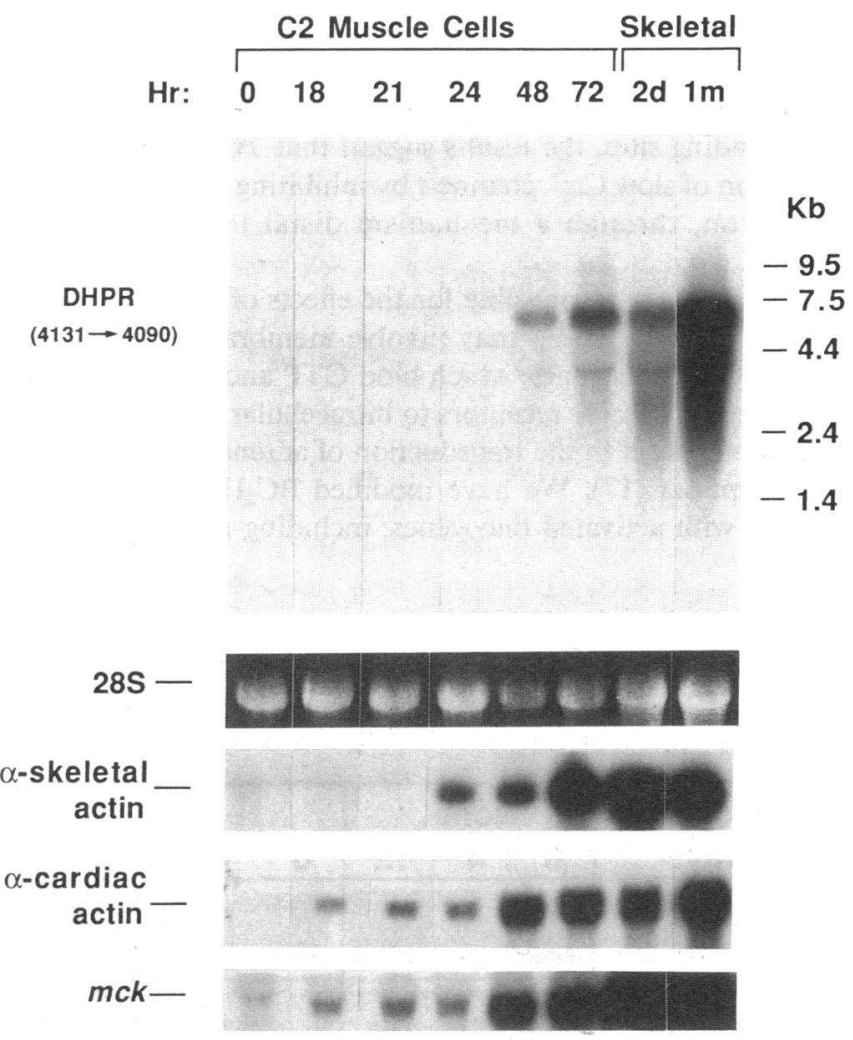

Figure 4. DHPR gene induction during myogenesis in vitro. Total cellular RNA isolated from C2 muscle cells after serum withdrawal for the intervals shown was analyzed by Northern blot hybridization as described in Methods and the legend to Fig. 1. Mouse skeletal muscle mRNA is shown for reference at the right of the figure. Comparable results were obtained with DHPR 42-mer used here and with the 5' 60 -mer. The exposures used for $m c k$ and the $\alpha$-actins were selected to permit comparable hybridization signals in $\mathrm{C} 2$ muscle cells $72 \mathrm{~h}$ after mitogen withdrawal. 


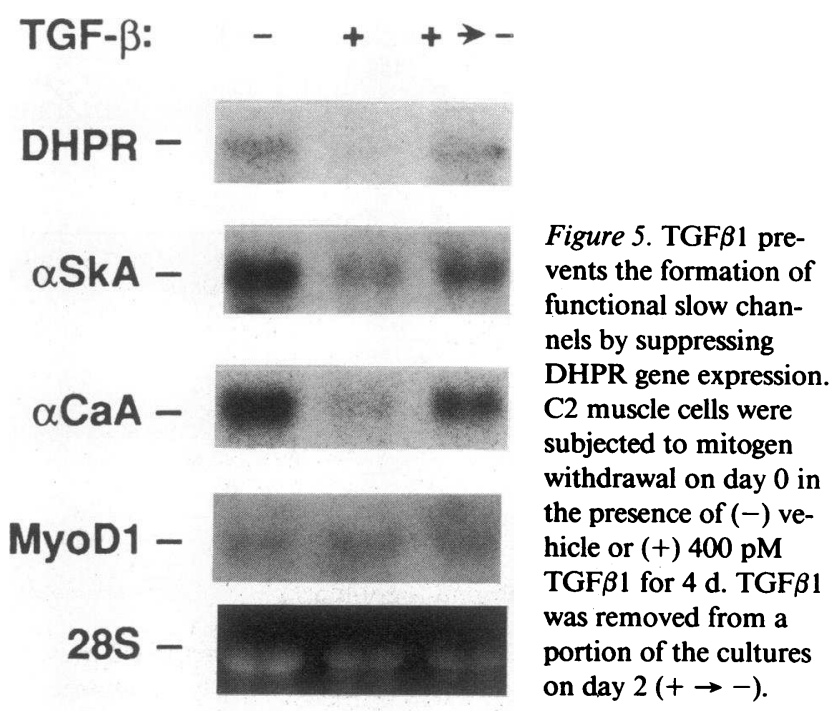

sion was reversibly suppressed by $\sim 80 \%$ (Fig. 5). This finding concurs with the known ability of TGF $\beta 1$ to inhibit the induction of muscle-specific genes $(15,16)$, as illustrated for the $\alpha$-actins. In contrast, TGF $\beta 1$ did not suppress the myogenic determination gene, MyoD1, whose expression had been reported to be constitutive within the myogenic lineage (39); recently, TGF $\beta 1$ has been shown to inhibit MyoD1 gene expression, at 10-fold higher concentrations than in the present study (49). Taken together with the previous evidence that TGF $\beta 1$ blocks the appearance of functional slow channels and DHP binding sites, the results suggest that TGF $\beta 1$ affects the formation of slow $\mathrm{Ca}^{2+}$ channels by inhibiting $\alpha_{1}$ subunit gene expression, through a mechanism distal to the action of MyoD1.

The pathway responsible for the effects of peptide growth factors including TGF $\beta$ may involve membrane proteins encoded by ras oncogenes, which bind GTP and are believed to couple growth factor receptors to intracellular effectors, much as G-proteins act in the transduction of adrenergic agonists or neuropeptides (17). We have modified $\mathrm{BC}_{3} \mathrm{H} 1$ cells by gene transfer with activated oncogenes, including ras $(12,18,43)$.
We showed that ras selectively prevents the appearance of channels that require serum withdrawal, but has no effect on the $\mathrm{K}^{+}$channels found in $\mathrm{BC}_{3} \mathrm{H} 1$ cells, which are expressed equally in differentiated and in proliferating cells (12). The Northern blot in Fig. 6 demonstrates that an oligonucleotide probe specific for DHPR mRNA in skeletal muscle also identified a $6.5-\mathrm{kb}$ transcript in differentiated $\mathrm{BC}_{3} \mathrm{H} 1$ cells. This finding agrees with the fact that slow channels in the nonfusing $\mathrm{BC}_{3} \mathrm{H} 1$ cell line have kinetic and ligand-binding properties that best resemble those found in skeletal muscle, not smooth muscle (12-14).

As in C2 cells, DHPR mRNA was induced by serum withdrawal (Fig. 6), whereas DHPR mRNA was not detected in $\mathrm{BC}_{3} \mathrm{H} 1$ cells stably transfected with a mutant ras allele (Fig. 6), in which neither functional slow channels nor DHP binding sites are detected $(12,13)$. On the other hand, DHPR gene expression was decreased, but not prevented, in cell lines expressing other activated oncogenes $(e r b \mathrm{~B}$ and $m y c)$, in which the accumulation of $\mathrm{Ca}^{2+}$ channels is merely delayed (12). These results do not preclude more complete inhibition of DHPR at higher copy number or levels of oncogene expression than those achieved in the particular cell lines studied. Nonetheless, in every instance examined, the presence, absence, or reduction of calcium current found previously in these cell lines (which need not involve altered channel synthesis) was associated with the presence, absence, or reduction of DHPR mRNA, respectively. Thus, the control of $\mathrm{Ca}^{2+}$ current density in transfected $\mathrm{BC}_{3} \mathrm{H} 1$ cells occurs in large part at the level of DHPR gene induction.

Notwithstanding the absence of $\alpha$-bungarotoxin binding sites in the ras-transfected cells (18), in contrast ras did not abolish the induction of $\mathrm{nAchR} \delta$, whose potential regulation by transfected oncogenes has not previously been examined. nAchR $\delta$ mRNA was upregulated 10-fold in ras-transfected $\mathrm{BC}_{3} \mathrm{H} 1$ cells after mitogen withdrawal, and the level of expression was roughly equivalent to that attained in control cells (Fig. 6). Since $\mathrm{BC}_{3} \mathrm{H} 1$ muscle cells differentiate through a mechanism independent of MyoD1 $(39,50)$, to exclude the possibility that induction of $n A c h R \delta$ in the presence of a transforming ras gene was merely due to an anomaly in their myogenic program, DHPR and $n A$ chR $\delta$ transcript accumu-

\begin{tabular}{|c|c|c|c|c|c|c|c|c|c|c|c|c|}
\hline \multirow{2}{*}{$\begin{array}{c}\text { Oncogene: } \\
\text { Day: }\end{array}$} & \multicolumn{3}{|c|}{ None } & \multicolumn{3}{|c|}{ H-ras } & \multicolumn{3}{|c|}{ erb B } & \multicolumn{3}{|c|}{ myc } \\
\hline & 0 & 4 & 12 & 0 & 4 & 12 & 0 & 4 & 12 & 0 & 4 & 12 \\
\hline DHPR & & & $=8$ & & & & & 20 & $e^{2}$ & & & \\
\hline nAchR $\delta$ & & & $=0$ & & & * & & $e^{2}$ & se & & te & 2 \\
\hline MLC3 & & & 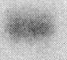 & & & & & & 2 & & & \\
\hline$\alpha$ SkA & & 20 & 5 & , & & & tes & & & & & \\
\hline$\alpha \mathrm{CaA}$ & & & & & & & & & 20 & & & as \\
\hline
\end{tabular}

Figure 6. An activated ras oncogene prevents DHPR gene induction through a mechanism that is permissive for expression of $n A c h R \delta$. RNA was isolated and analyzed following mitogen withdrawal for the intervals shown. The construction and characterization of clonal $\mathrm{BC}_{3} \mathrm{H} 1$ cell lines, stably cotransfected with pSV2neo and oncogene expression vectors, have been detailed previously $(13,19,44)$. ErbB denotes v-erbB, the avian erythroblastosis viral genome deleted in the erbA and gag sequences, under the transcriptional control of the viral LTR. The myc expression vector contains murine c-myc exons 2 and 3 downstream from the SV40 promoter, and $\mathrm{H}$-ras indicates the $\mathrm{Val}^{12}$ allele of human c-H-ras-1, under the control of its own promoter. 
lation also was investigated in $\mathrm{C} 2$ cells containing the activated ras allele, which similarly fail to bind $\alpha$-bungarotoxin (19). In concordance with the results shown for $\mathrm{BC}_{3} \mathrm{H} 1$ cells, $\mathrm{nAchR} \delta$ mRNA was readily detected in ras-transfected C2 cells following serum withdrawal, whereas the DHPR transcript was suppressed (Fig. 7). Thus, the inhibition of DHPR gene expression by ras does not merely involve a block to the myogenic pathway.

DHP receptor gene expression is relatively insensitive to denervation. To test the prediction, suggested by the existing biophysical data, that muscle activity also might exert differing effects on DHPR vs. nAchR gene expression, we analyzed RNA from fast and slow skeletal muscle $15 \mathrm{~d}$ after denervation, using the contralateral muscles as control (Fig. 8). No more than a 0.35 - to 0.52 -fold increase in DHPR gene expression was detected. These results contrast with the upregulation of mRNA encoding nAchR $\delta$ (up to eightfold). Qualitatively similar results were obtained at earlier time points, as well. Moreover, in agreement with a recent study (51), denervated soleus muscle also exhibited reciprocal effects on the two sarcomeric actin genes: decreased expression of $\alpha$-skeletal actin mRNA, concomitant with increased abundance of the $\alpha$-cardiac actin transcript (up to 4.5-fold) associated with embryonic and neonatal skeletal muscle. Thus, changes in DHPR gene expression after denervation were $\sim 10$-fold less than in the other muscle-specific genes which were-tested.

To test the related hypothesis that stimulatory and inhibitory DHPs might themselves influence DHPR gene expression, we subjected $C 2$ cells to serum withdrawal in the presence of vehicle alone, the optically pure DHP agonist (-)S Bay K 8644 (R5417), or the antagonist, nifedipine, at submaximal concentrations $(1 \mu \mathrm{M})$. At $1 \mu \mathrm{M}$, the amplitude of "slow" current elicited by voltage pulses to $0 \mathrm{mV}$ was increased fivefold by (-)S Bay K 8644 and decreased $60 \%$ by nifedipine (not shown). Under the conditions tested, nifedipine stimulated DHPR gene expression no more than 0.5-fold, at $2 \mathrm{~d}$ (Fig. 9). Unlike denervation, chronic exposure to nifedipine did not produce $a_{1}$ large increase in nAchR $\delta$ mRNA levels. In the presence of $(-)$ S Bay K 8644, little or no change in DHPR gene expression was measured; comparable results were obtained using the antagonist stereoisomer, (+R) Bay K 8644 (R4407; not shown). Thus, concentrations of DHPs sufficient to alter slow $\mathrm{Ca}^{2+}$ current up to fivefold did not exert potent effects on DHPR gene expression, in good agreement with the

\section{Mitogen}

Withdrawal:

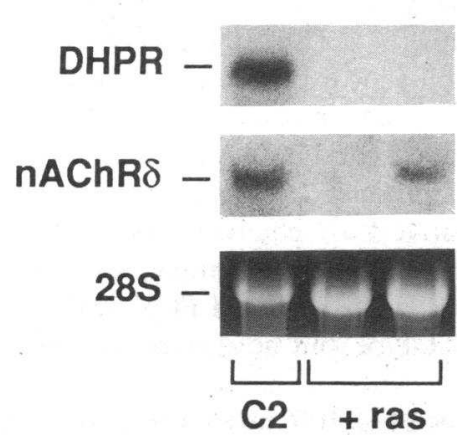

Figure 7. DHPR gene expression is extinguished in $\mathrm{C} 2$ muscle cells bearing the activated ras allele, whereas $\mathrm{nAChR} \delta$ mRNA is induced after serum withdrawal. C2 cells stably transfected with the same H-ras construct as in Fig. 6 were differentiated for $4 \mathrm{~d}$; the $\mathrm{C} 2$ cells included as a positive control were differentiated for $7 d$ and are not intended for direct comparison.

\section{A. Soleus}

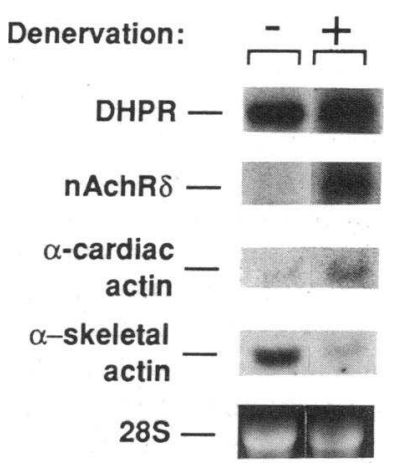

Figure 8. DHPR gene expression in the soleus and flexor digitorum longus after denervation. $(+)$ Denervated and $(-)$ contralateral control muscles were analyzed $15 \mathrm{~d}$ after nerve transection.

limited degree of homologous regulation shown by DHP binding in other excitable cells (1).

\section{Discussion}

DHPR gene expression during myogenesis in vivo. Our experimental findings suggest the conclusion that DHPR gene expression in mouse skeletal muscle is both tissue-specific and developmentally regulated in vivo. Previous studies have shown that the proportional volume of muscle fiber occupied by the T-tubular system increases about fivefold in mouse skeletal muscle, during the first few weeks after birth (45), as does the density of functional slow $\mathrm{Ca}^{2+}$ channels (29). Both slow current (52) and DHP binding sites (53) also increase after birth in rat skeletal muscle. In contrast, DHP-insensitive, T-type $\mathrm{Ca}^{2+}$ channels become undetectable within three to four weeks of birth $(29,52)$. The results favor the interpretation that quantitative differences in slow $\mathrm{Ca}^{2+}$ channel expression during myogenesis involve, at least in part, control at a pretranslational level. The absence of a hybridization signal in ventricular muscle and brain agrees with known disparities

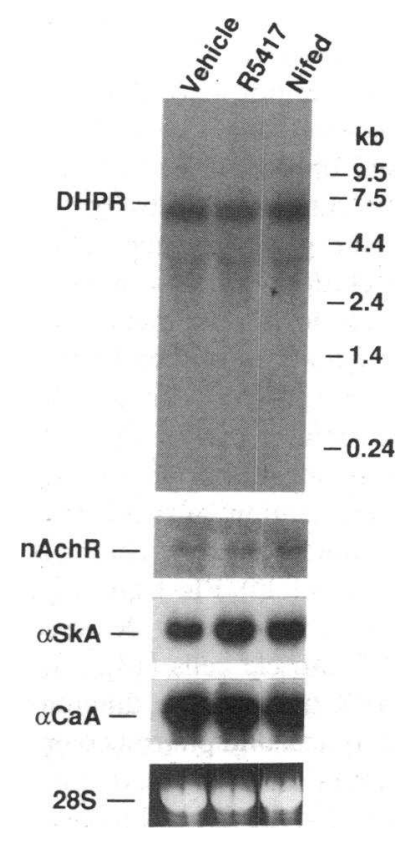

Figure 9. DHPR gene expression in $\mathrm{C} 2$ muscle cells subjected to mitogen withdrawal in the presence of vehicle or the DHPs shown $(1 \mu \mathrm{M})$. Similar results were obtained at $20 \mu \mathrm{M}$. 
between the DHP-sensitive slow channel in skeletal muscle and classical L-type channels in other excitable tissues, and agrees with recent confirmation that the DHP receptor in other cell types may possess a differing, though related, primary structure (48).

DHPR mRNA was identified in both fast (latissimus dorsi) and slow (soleus) muscle. Despite differences in the voltagedependence of both asymmetric charge movement and the inactivation of excitation-contraction coupling (reviewed in reference 54), this finding is not unexpected, as slow $\mathrm{Ca}^{2+}$ channels in fast and slow muscle display similar kinetics and DHP sensitivity (44). The apparent abundance of DHPR mRNA in fast versus slow muscle varied no more than twofold, in agreement with their relative T-tubular volume (45), slow current amplitude, asymmetric charge movement, and density of DHP binding sites (44). More precise analysis of these and other small fluctuations in transcript abundance can best be performed by quantitative nuclease protection, using the autologous murine DHPR $\alpha_{1}$ subunit sequence as the hybridization probe.

DHPR gene expression during myogenesis in vitro. In agreement with the conclusion that the increase in slow current density after birth could be accounted for by increased DHPR mRNA abundance, in cultured muscle cells we found that the induction of slow $\mathrm{Ca}^{2+}$ channels by serum withdrawal (and their suppression by TGF $\beta 1$ or activated ras genes) all involve control at a pretranslational level. Both DHPR mRNA and functional DHP binding sites appeared during the interval from 24 to $48 \mathrm{~h}$ after serum withdrawal, and a single class of the binding sites existed, with an affinity typical of DHP receptors in adult skeletal muscle. Therefore, even if a second step were rate-limiting for the binding site to become functional, the latency between message induction and expression of the mature receptor must be less than $24 \mathrm{~h}$ (cf. 25). It is unknown whether ion movement through slow $\mathrm{Ca}^{2+}$ channels is responsible, even in part, for the effects of extracellular $\mathrm{Ca}^{2+}$ on muscle development (55). Although the appearance of $\mathrm{Ca}^{2+}$ currents is one of the earliest events during myogenesis in certain primitive marine chordates (56), in $\mathrm{C} 2$ muscle cells, the genes encoding $\alpha$-cardiac actin, $\alpha$-skeletal actin, and $m c k$ each were induced before slow channels could be detected by Northern blot, ligand binding, or even whole-cell clamp analysis. These experimental findings do not exclude a possible role for DHP-sensitive channels at densities too low to be detected by the three procedures used, or bear on the likelihood that DHP-sensitive channels might participate in the activity-dependent modulation of muscle-specific genes at later stages (57). In agreement with this interpretation, dysgenic muscle lacking slow channels also is reported to form sarcomeres (58) and express creatine kinase (59), though at diminished levels.

Despite the theoretical possibility that growth factors might inhibit the opening probability for slow channels, through protein kinase $C$ or other transduction pathways (e.g., 60), the results shown here support the interpretation, instead, that TGF $\beta 1$ prevents the appearance of functional slow channels (and DHP binding sites) at the level of DHPR transcript abundance. Furthermore, TGF $\beta 1$ does not acutely decrease the amplitude of slow current in C2 muscle cells (14). The presence of the skeletal muscle DHPR transcript in differentiated $\mathrm{BC}_{3} \mathrm{H} 1$ cells concurs with biophysical and pharmacological evidence that $\mathrm{BC}_{3} \mathrm{H} 1$ cells express DHP-sensitive $\mathrm{Ca}^{2+}$ channels that are distinct from the L-type high-threshold channels of smooth muscle, cardiac muscle and neurons, and are identical in most respects to those found in $\mathrm{C} 2$ cells or skeletal muscle transverse tubules. That $\mathrm{BC}_{3} \mathrm{Hl}$ cells have the properties of skeletal muscle cells (but are defective for terminal differentiation) is substantiated by their expression of sarcomeric muscle contractile protein genes (61), as well as the muscle determination gene, myogenin (50). Conversely, the absence of functional slow $\mathrm{Ca}^{2+}$ channels in $\mathrm{BC}_{3} \mathrm{H} 1$ cells stably transfected with an activated ras gene can, like the action of extracellular TGF $\beta$, be accounted for by a block to accumulation of the DHPR transcript. These findings demonstrate that a guanine nucleotide-binding protein can alter calcium current by regulating DHPR gene expression, in addition to the direct effects of other $\mathrm{G}$ proteins on $\mathrm{Ca}^{2+}$ channel gating (e.g., 60). Our investigations are consistent with recent evidence that ras can suppress the function of a regulatory DNA motif shared by several unrelated muscle-specific genes (21).

An unanticipated finding in the present study was the induction of $\mathrm{nAchR} \delta$ gene expression in ras-transfected $\mathrm{BC}_{3} \mathrm{H} 1$ and $\mathrm{C} 2$ cells after serum withdrawal, which is noteworthy in several respects. First, the presence of nAchR $\delta$ mRNA indicates that activation of c-H-ras does not preclude the appearance of all muscle differentiation products, as might be inferred from previous results $(12,18,19,62,63)$. A mechanistic basis for the disparate effects of ras on multiple muscle-specific genes would be conjectural at present. However, studies with a reversibly inducible ras expression vector indicate that impairment of differentiation is titratable (62), suggesting that the threshold for inhibition by ras might vary systematically between genes. Second, analogous dosage effects might conceivably contribute to the more complete inhibition of $\mathrm{Ca}^{2+}$ channel formation by ras than by other oncogenes (cf. 43, 64), and the possibility therefore exists that properties differing, for example, between ras- and erbB-transfected cells are not inherent to these genes. However, although equivalency of dosage has not been yet established for v-erbB, the ras-transfected $\mathrm{BC}_{3} \mathrm{H} 1$ cells contain only a single copy of the activated allele, under the control of its own promoter, and c-H-ras mRNA abundance is increased no more than threefold (18). By contrast, the SV40-driven c- $m y c$ gene produced $m y c$ mRNA levels that were 20- to 40 -fold greater than those in control cells (43). Other studies demonstrating "complete" inhibition of myogenesis by v-erbB $(65), \mathrm{v}-m y c(65,66)$ or activated $\mathrm{c}-m y c$ genes (64) have each retained at least $2 \%$ fetal bovine serum in the media used to induce differentiation, a concentration four times greater than that used here.

Furthermore, the presence of $\mathrm{nAchR} \delta$ mRNA in both ras-transfected $\mathrm{BC}_{3} \mathrm{H} 1$ and $\mathrm{C} 2$ cells, which fail to express $\alpha$ bungarotoxin binding sites $(18,19)$, demonstrates that suppression of an ion channel need not involve each subunit mRNA. Activated ras genes also fail to suppress the nAchR $\alpha$ gene in transfected $C 2$ cells (67). Thus, the highly regulated pattern of DHPR $\alpha_{1}$ subunit gene expression neither is a foregone conclusion, nor can be predicted on the basis of measurements of current density and ligand binding. Finally, ras and other activated oncogenes produce contrasting effects in cell lineages whose DHP-sensitive $\mathrm{Ca}^{2+}$ channels differ from the slow channels in skeletal muscle. For example, ras leads to induction of calcium channels in neuronal PC12 cells (67a), and selectively suppresses T-type, but not L-type, channels in NIH 3T3 fibroblasts (68).

Conversely, the absence of DHPR mRNA despite contin- 
ued MyoD1 gene expression in C2 cells treated with TGF $\beta 1$ also merits comment. Though MyoD1 itself recently was shown to be repressed by TGF $\beta 1$ (49), as well as by ras (63, 67 ), suggesting that the peptide might act on the myogenic pathway by inhibiting this muscle regulatory gene, this was achieved at tenfold higher concentrations than those in the present study, may have been further potentiated by the inclusion of 5\% horse serum, and was demonstrated only in myoblasts derived from a pluripotent cell line, 10T1/2, by exposure to 5-azacytidine. Moreover, the fact that exogenous MyoD1 genes fail to overcome the block to differentiation created by TGF $\beta$ (49) or by transient transfection with ras $(67 ;$ cf. 63$)$ concurs with our finding that repression of DHPR by TGF $\beta 1$ can coexist with expression of the endogenous MyoDl gene. MyoD1 is a nuclear phosphoprotein (69), suggesting the likelihood that posttranslational events may confer the ability to transactivate muscle-specific genes.

DHPR gene expression and physiological adaptation. In addition to regulated expression during muscle ontogeny, certain ion channels (and other differentiation products) also are subjected to quantitative or qualitative control in postnatal muscle fibers by physiological signals such as denervation, cross-innervation, activity and manipulation of ion flux $(27-29,57)$. The possibility has been suggested that cellular oncogenes might serve as "third messengers" that couple membrane currents to adaptive changes in gene expression in electrically excitable cells (70). However, in agreement with the finding that denervation fails to increase asymmetric charge movement (31) or $\mathrm{Ca}^{2+}$ current density (29; cf. 30$)$, we observed that denervation exerts relatively little effect on DHPR gene expression, under conditions that markedly alter genes encoding other ion channels in muscle. In principle, DHP ligands might also be expected to influence DHPR expression, yet neither an agonist nor an antagonist altered DHPR gene expression in C2 cells by more than $60 \%$. These changes were one-fifth or less as great as those reported for $\mathrm{Na}^{+}$ channel mRNA following denervation (26) or inhibition of $\mathrm{Na}^{+}$current (28) in rat skeletal muscle. Possible impediments to resolving this issue in culture include disparities between acute effects versus chronic exposure to DHPs, consequences of resting potential (71), steady-state inactivation, and residual current or charge movement. Alternative tests of the role of membrane activity may be instructive (57).

The observations in the present report suggest that both the developmental regulation and tissue-specificity of $\mathrm{Ca}^{2+}$ channel expression are achieved in part at the level of DHPR transcript availability. In contrast, DHPR gene expression was relatively insensitive to physiological events, such as denervation and channel antagonists, which produce diverse alterations in other membrane or contractile proteins in skeletal muscle. This distinction may be a more general phenomenon, as shown by studies of cardiac muscle. Though adaptation to a hemodynamic load downregulates cardiac expression of the $\mathrm{Ca}^{2+}$ ATPase (72), evokes the fetal isoforms of sarcomeric proteins $(73,74)$, and reinduces ventricular expression of atrial natriuretic factor $(73,74)$, in contrast, DHP binding (per gram of ventricle or milligram protein) does not change (75). Thus, the density of $\mathrm{Ca}^{2+}$ channels is unlikely to account for the increased $\mathrm{Ca}^{2+}$ current observed in ventricular myocytes of hypertensive rats (76). The largest changes in gene expression produced by denervation each involve transitions toward embryonic isoforms (tetrodotoxin insensitive $\mathrm{Na}^{+}$channels [77], $\alpha$-cardiac actin [51], and acetylcholine receptors with embryonic channel properties, in which the $\gamma$ sub-unit is re-expressed [78]), whereas only a single class of DHP receptor sites $(13,53)$ and DHP-sensitive $\mathrm{Ca}^{2+}$ channels $(12,14,29,52)$ appears to exist during mammalian skeletal muscle development. Taken together with other evidence that $\mathrm{Ca}^{2+}$ channel density varies little in mammalian skeletal muscle once terminal differentiation has occurred, the present study fosters speculation that the existence of diverse pathways that alter $\mathrm{Ca}^{2+}$ channel opening may obviate, in part, the need for channel number to be highly regulated by denervation or other physiologic interventions.

\section{Acknowledgments}

We are grateful to E. N. Olson for a critical review of the manuscript and the transfected $\mathrm{C} 2$ cell samples, and to $\mathrm{L}$. Chan for oligonucleotide synthesis. We thank A. M. Brown for facilities and support early in the course of this work; A. Skattebol for the C2 DHP binding study; L. Michael and P. Jackson for assistance in denervation; J. L. Barker for permission to cite unpublished results; M. B. Perryman for the $m c k$ probe and numerous discussions; A. M. Means and C. Seidel for the use of densitometers; F. Ervin for technical assistance; S. Terry for preparation of the manuscript; and R. Roberts for generous support and encouragement.

This investigation was supported by grants to M.D.S. from the American Heart Association, Texas Affiliate (87R-179) and the National Science Foundation (DCB-8711313); an American College of Cardiology/Merck Foundation Fellowship to M. S. Wathen; and a National Research Service Award to J. M. Caffrey (AR07546). H.-T. Shih and M. S. Wathen are Fellows of the American Heart Association-Bugher Foundation Center for Molecular Biology of the Cardiovascular System. M. D. Schneider is an Established Investigator of the American Heart Association. H.-T. Shih is the recipient of an American Federation for Clinical Research Trainee Award for the investigations reported here.

\section{References}

1. Ferrante, J., and D. J. Triggle. 1989. Drug- and disease-induced regulation of voltage-dependent calcium channels. J. Pharm. Exp. Ther. (In press).

2. Delorme, E. M., and R. McGee Jr. 1986. Regulation of voltagedependent $\mathrm{Ca}^{2+}$ channels of neuronal cells by chronic changes in membrane potential. Brain Res. 397:189-192.

3. Navarro, J. 1986. Dihydropyridine methyl- ${ }^{3} \mathrm{H}$ PN200-1 10 binding and myogenesis in intact muscle cells in vitro. $J$. Neurochem. 46:1166-1169.

4. Wagner, J. A., I. J. Reynolds, H. F. Weisman, P. Dudeck, M. L. Weisfeldt, and S. H. Snyder. 1986. Calcium antagonist receptors in cardiomyopathic hamster: selective increases in heart, muscle, brain. Science (Wash. DC). 232:515-518.

5. Wagner, J. A., F. L. Sax, H. F. Weisman, J. Porterfield, C. McIntosh, M. L. Weisfeldt, S. H. Snyder, and S. E. Epstein. 1989. Calcium-antagonist receptors in the atrial tissue of patients with hypertrophic cardiomyopathy. N. Engl. J. Med. 1989 320:755-761.

6. Vaghy, P. L., J. Striessnig, K. Miwa, H.-G. Knaus, K. Itagaki, E. McKenna, H. Glossmann, and A. Schwartz. 1987. Identification of a novel 1,4-dihydropyridine- and phenylalkylamine-binding polypeptide in calcium channel preparations. J. Biol. Chem. 262:1433714342.

7. Tanabe, T., H. Takeshima, A. Mikami, V. Flockerzi, H. Takahashi, K. Kangawa, M. Kojima, H. Matsuo, T. Hirose, and S. Numa. 
1987. Primary structure of the receptor for calcium channel blockers for skeletal muscle. Nature (Lond.). 328:313-318.

8. Ellis, S. B., M. E. Williams, N. E. Ways, R. Brenner, A. H. Sharp, A. T. Leung, K. P. Campbell, E. McKenna, W. J. Koch, A. Hui, A. Schwartz, and M. M. Harpold. 1988. Sequence and expression of mRNAs encoding the alpha 1 and alpha 2 subunits of a DHP-sensitive calcium channel. Science (Wash. DC). 241:1661-1664.

9. Schwarz, T. L., B. L. Tempel, D. M. Papazian, Y. N. Jan, and L. Y. Jan. 1988. Multiple potassium-channel components are produced by alternative splicing at the Shaker locus in Drosophila. Nature (Lond.). 331:137-142.

10. Tanabe, T., K. G. Beam, J. A. Powell, and S. Numa. 1988. Restoration of excitation-contraction coupling and slow calcium current in dysgenic muscle by dihydropyridine receptor complementary DNA. Nature (Lond.). 336:134-139.

11. Perez-Reyes, E., H. S. Kim, A. E. Lacerda, W. Horne, X. Wei, D. Rampe, K. P. Campbell, A. M. Brown, and L. Birnbaumer. 1989. Induction of calcium currents by the expression of the $\alpha 1$-subunit of the dihydropyridine receptor from skeletal muscle. Nature (Lond.). 340:233-236

12. Caffrey, J. M., A. M. Brown, and M. D. Schneider. 1987. Mitogens and oncogenes can block the formation of specific voltagegated ion channels. Science (Wash. DC). 236:570-574.

13. Rampe, D. E., J. M. Caffrey, M. D. Schneider, and A. M. Brown. 1988. Control of the expression of the 1,4-dihydropyridine receptor in BC3H1 cells. Biochem. Biophys. Res. Commun. 152:769775.

14. Caffrey, J. M., A. M. Brown, and M. D. Schneider. $1989 . \mathrm{Ca}^{2+}$ and $\mathrm{Na}^{+}$currents in developing skeletal myoblasts are expressed in a sequential program: reversible suppression by transforming growth factor beta-1, an inhibitor of the myogenic pathway. J. Neurosci. 9:3443-3453.

15. Massagué, J., T. Cheifetz, S. Endo, and B. Nadal-Ginard. 1986. Type $\beta$ transforming growth factor is an inhibitor of myogenic differentiation. Proc. Natl. Acad. Sci. USA. 83:8206-8210.

16. Olson, E. N., E. Sternberg, J. S. Hu, G. Spizz, and C. Wilcox. 1986. Regulation of myogenic differentiation by type $\beta$ transforming growth factor. J. Cell Biol. 103:1799-1805.

17. Marshall, C. J. 1987. Oncogenes and growth control. Cell. 49:723-725.

18. Payne, P. A., E. N. Olson, P. Hsiau, R. Roberts, M. B. Perryman, and M. D. Schneider. 1987. An activated c-Ha-ras allele blocks the induction of muscle-specific genes whose expression is contingent on mitogen withdrawal. Proc. Natl. Acad. Sci. USA. 84:8956-8960.

19. Olson, E. N., G. Spizz, and M. A. Tainsky. 1987. The oncogenic forms of $\mathrm{N}$-ras or $\mathrm{H}$-ras prevent skeletal myoblast differentiation. Mol. Cell. Biol. 7:2104-2111.

20. Schneider, M. D., and E. N. Olson. 1988. Control of myogenic differentiation by cellular oncogenes. Mol. Neurobiol. 2:1-39.

21. Sternberg, E. A., G. Spizz, M. E. Perry, and E. N. Olson. 1989. A ras-dependent pathway abolishes activity of a muscle-specific enhancer upstream from the muscle creatine kinase gene. Mol. Cell. Biol. 9:594-601.

22. Kedes, L. H., and F. E. Stockdale, editors. 1989. Cellular and Molecular Biology of Muscle Development. Alan R. Liss Co., New York.

23. Black, R., D. Goldman, S. Hochswender, S. Lindstrom, and Z. W. Hall. 1987. Genetic variants of C2 muscle cells that are defective in synthesis of the alpha-subunit of the acetylcholine receptor. J. Cell Biol. 105:1329-1336.

24. Schmidt, J. W., and W. A. Catterall. 1986. Palmitylation, sulfation, and glycosylation of the alpha subunit of the sodium channel. Cell. 46:437-445.

25. Wollner, D. A., R. Scheinman, and W. A. Catterall. 1988 Sodium channel expression and assembly during development of retinal ganglion cells. Neuron. 1:727-739.

26. Cooperman, S. S., S. A. Grubman, R. L. Barchi, R. H. Good- man, and G. Mandel. 1987. Modulation of sodium-channel mRNA levels in rat skeletal muscle. Proc. Natl. Acad. Sci. USA. 84:8721-8725.

27. Goldman, D., H. R. Brenner, and S. Heinemann. 1988. Acetylcholine receptor $\alpha-, \beta-, \gamma-$, and $\delta$-subunit mRNA levels are regulated by muscle activity. Neuron. 1:329-333.

28. Offord, J., and W. A. Catterall. 1989. Electrical activity, cAMP, and cytosolic calcium regulate mRNA encoding sodium channel $a$ subunits in rat muscle cells. Neuron. 2:1447-1452.

29. Gonoi, T., and S. Hasegawa. 1988. Post-natal disappearance of transient calcium channels in mouse skeletal muscle: effects of denervation and culture. J. Physiol. 401:617-637.

30. Schmid, A., J.-F. Renaud, M. Fosset, J.-P. Meaux, and M. Lazdunski. 1984. The nitrendipine-sensitive $\mathrm{Ca}^{++}$channel in chick muscle cells and its appearance during myogenesis in vitro and in vivo. J. Biol. Chem. 259:11366-11372.

31. Dulhunty, A. F., and P. W. Gage. 1983. Asymmetric change movement in slow- and fast-twitch mammalian muscle fibers in normal and paraplegic rats. J. Physiol. 341:213-231.

32. Chirgwin, J. M., A. E. Przybyla, R. J. MacDonald, and W. J. Rutter. 1979. Isolation of biologically active ribonucleic acid from sources enriched in ribonuclease. Biochemistry. 18:5294-5299.

33. Chomczynski, P., and N. Sacchi. 1987. Single-step method of RNA isolation by acid guanidinium thiocyanate-phenol-chloroform extraction. Anal. Biochem. 162:156-159.

34. Dillmann, W. H., A. Barrieux, W. E. Neeley, and P. Contreras 1983. Influence of thyroid hormone on the in vitro translational activity of specific mRNAs in the rat heart. J. Biol. Chem. 258:7738-7745.

35. Alonso, S., A. Minty, Y. Bourlet, and M. Buckingham. 1986. Comparison of three actin-coding sequences in the mouse; evolutionary relationships between the actin genes of warm-blooded vertebrates. J. Mol. Evol. 23:11-22.

36. Leader, D. P., I. Gall, and P. C. Campbell. 1986. The structure of a cDNA clone corresponding to mouse cardiac muscle actin mRNA. Biosci. Rep. 6:741-747.

37. LaPolla, R. J., K. M. Mayne, and N. Davidson. 1984. Isolation and characterization of a cDNA clone for the complete protein coding region of the delta-subunit of the mouse acetylcholine receptor. Proc. Natl. Acad. Sci. USA. 81:7970-7974.

38. Perryman, M. B., S. A. Kerner, T. J. Bohlmeyer, and R. Roberts. 1986. Isolation and sequence analysis of a full length cDNA for human M creatine kinase. Biochem. Biophys. Res. Commun. 140:981-989.

39. Davis, R. L., H. Weintraub, and A. B. Lassar. 1987. Expression of a single transfected cDNA converts fibroblasts to myoblasts. Cell. 51:987-1000.

40. Feinberg, A. P., and B. Vogelstein. 1983. A technique for radiolabelling DNA endonuclease fragment to high specific activity. Anal. Biochem. 132:6-13.

41. Yaffe, D., and O. Saxel. 1977. Serial passaging and differentiation of myogenic cells isolated from dystrophic mouse muscle. Nature (Lond.). 270:725-727.

42. Schubert, D., A. J. Harris, C. E. Devine, and S. Heinemann. 1974. Characterization of a unique muscle cell line. J. Cell Biol. 61:398-413.

43. Schneider, M. D., M. B. Perryman, P. A. Payne, G. A. Spizz, R. Roberts, and E. N. Olson. 1987. Autonomous expression of c-myc in $\mathrm{BC}_{3} \mathrm{H} 1$ cells partially inhibits but does not prevent myogenic differentiation. Mol. Cell. Biol. 7:1973-1977.

44. Lamb, G. D., and T. Walsh. 1987. Calcium currents, charge movement and dihydropyridine binding in fast- and slow-twitch muscles of rat and rabbit. J. Physiol. 393:595-617.

45. Luff, A. R., and H. L. Atwood. 1971. Changes in the sarcoplasmic reticulum and transverse tubular system of fast and slow skeletal muscles of the mouse during postnatal development. J. Cell Biol. 51:369-383.

46. Aviv, H., and P. Leder. 1972. Purification of biologically active 
globin messenger RNA by chromatography on oligothymidylic acidcellulose. Proc. Natl. Acad. Sci. USA. 69:1408-1412.

47. Lotan, I., P. Goelet, A. Gigi, and N. Dascal. 1989. Specific block of calcium channel expression by a fragment of dihydropyridine receptor cDNA. Science (Wash. DC). 243:666-669.

48. Mikami, A., K. Imoto, T. Tanabe, T. Niidome, Y. Mori, H. Takeshima, S. Narumiya, and S. Numa. 1989. Primary structure and functional expression of the cardiac dihydropyridine-sensitive calcium channel. Nature (Lond.). 340:230-233.

49. Vaidya, T. B., S. J. Rhodes, E. J. Taparowsky, and S. F. Konieczny. 1989. Fibroblast growth factors and transforming growth factor $\beta$ repress transcription of the myogenic regulatory gene MyoDl. Mol. Cell. Biol. 9:3576-3579.

50. Edmondson, D. G., and E. N. Olson. 1989. A gene with homology to the myc similarity region of MyoD1 is expressed during myogenesis and is sufficient to activate the muscle differentiation program. Genes \& Dev. 3:628-640.

51. Shimizu, N., S. Kamel-Reid, and R. Zak. 1988. Expression of actin mRNAs in denervated chicken skeletal muscle. Dev. Biol. $128: 435-440$

52. Beam, K. G., and C. M. Knudson. 1988. Effect of postnatal development on calcium currents and slow charge movement in mammalian skeletal muscle. J. Gen. Physiol. 91:799-815.

53. Kazazoglou, T., A. Schmid, A.-F. Renaud, and M. Lazdunski. 1983. Ontogenic appearance of $\mathrm{Ca}^{2+}$ channels characterized as binding sites for nitrendipine during development of nervous, skeletal, and cardiac, muscle in the rat. FEBS (Fed. Eur. Biochem. Soc.) Lett. 164:75-79.

54. Chua, M., and A. F. Dulhunty. 1988. Inactivation of excitation-contraction coupling in rat extensor digitorum longus and soleus muscles. J. Gen. Physiol. 91:737-757.

55. Endo, T., and B. Nadal-Ginard. 1987. Three types of musclespecific gene expression in fusion-blocked rat skeletal muscle cells Translational control in EGTA-treated cells. Cell. 49:515-528.

56. Simoncini, L., M. L. Block, and W. J. Moody. 1988. Lineagespecific development of calcium currents during embryogenesis. Science (Wash. DC). 242:1572-1575.

57. Kraus, W. E., T. S. Bernard, and R. S. Williams. 1989. Interactions between sustained contractile activity and $\beta$-adrenergic receptors in regulation of gene expression in skeletal muscles. Am. J. Physiol. 256:C506-C514.

58. Rieger, F., M. Pincon-Raymond, A. M. Tassin, L. Garcia, G. Romey, M. Fosset, and M. Lazdunski. 1987. Excitation-contraction uncoupling in the developing skeletal muscle of the muscular dysgenesis mouse embryo. Biochimie. 69:411-417.

59. Oppenheim, R. W., L. Houenou, M. Pincon-Raymond, J. A. Powell, F. Rieger, and L. J. Standish. 1986. The development of motoneurons in the embryonic spinal cord of the mouse mutant, muscular dysgenesis ( $\mathrm{mdg} / \mathrm{mdg}$ ): survival, morphology, and biochemical differentiation. Dev. Biol. 114:426-436.

60. Yatani, A., J. Codina, Y. Imoto, J. P. Reeves, L. Birnbaumer, and A. M. Brown. 1987. A G protein directly regulates mammalian cardiac calcium channels. Science (Wash. DC). 238:1288-1292.

61. Taubman, M. B., C. W. J. Smith, S. Izumo, J. W. Grant, T. Endo, A. Andreadis, and B. Nadal-Ginard. 1989. The expression of sarcomeric muscle specific contractile protein genes in $\mathrm{BC} 3 \mathrm{H} 1$ cells. BC $3 \mathrm{H} 1$ cells resemble skeletal myoblasts that are defective for commitment to terminal differentiation. J. Cell Biol. 108:1799-1806.

62. Gossett, L. A., W. Zhang, and E. N. Olson. 1988. Dexamethasone-dependent inhibition of differentiation of $\mathrm{C} 2$ myoblasts bearing steroid-inducible N-ras oncogenes. J. Cell Biol. 106:2127-2137.
63. Konieczny, S. F., B. L. Drobes, S. L. Menke, and E. J. Taparowsky. 1989. Inhibition of myogenic differentiation by the $\mathrm{H}$-ras oncogene is associated with the down-regulation of the MyoD1 gene. Oncogene. 4:473-481.

64. Denis, N., S. Blanc, M. P. Leibovitch, N. Nicolaiew, F. Dautry, M. Raymondjean, J. Kruth, and A. Kitzis. 1987. c-Myc oncogene expression inhibits the initiation of myogenic differentiation. Exp. Cell Res. 172:212-217.

65. Falcone, G., F. Tatò, and S. Alemà. 1985. Distinctive effects of the viral oncogenes myc, erb, fps, and src on the differentiation program of quail myogenic cells. Proc. Natl. Acad. Sci. USA. 82:426-430.

66. La Rocca, S. A., M. Grossi, G. Falcone, S. Alemà, and F. Tatò. 1989. Interaction with normal cells suppresses the transformed phenotype of v-myc-transformed quail muscle cells. Cell. 58:123-131.

67. Lassar, A. B., M. J. Thayer, R. W. Overell, and H. Weintraub. 1989. Transformation by activated ras or fos prevents myogenesis by inhibiting expression of MyoD1. Cell. 58:659-667.

67a. Noda, M., M. Ko, A. Ogura, D. Liu, T. Amano, T. Takano, and Y. Ikawa. 1985. Sarcoma viruses carrying ras oncogenes induce differentiation-associated properties in a neuronal cell line. Nature (Lond.). 318:73-75.

68. Chen, C., M. J. Corbley, T. M. Roberts, and P. Hess. 1988. Voltage-sensitive calcium channels in normal and transformed 3T3 fibroblasts. Science (Wash. DC). 239:1024-1026.

69. Tapscott, S. J., Rl. L. Davis, M. J. Thayer, P.-F. Cheng, H. Weintraub, and A. B. Lassar. 1988. MyoD1: a nuclear phosphoprotein requiring a myc homology region to convert fibroblasts to myoblasts. Science (Wash. DC). 242:405-411.

70. Morgan, J. I., and T. Curran. 1986. Role of ion flux in the control of c-fos expression. Nature (Lond.). 322:552-555.

71. Kass, R. S. 1987. Voltage-dependent modulation of cardiac calcium channel current by optical isomers of Bay $\mathrm{K}$ 8644: implications for channel gating. Circ. Res. 61:I-1-I-5.

72. Lompré, A.-M., D. Levitsky, D. de la Bastie, J.-J. Mercadier, L. Rappaport, and K. Schwartz. 1989. Function of the sarcoplasmic reticulum and expression of its $\mathrm{Ca}^{2+} \mathrm{ATPase}$ gene in pressure overloaded rat myocardium. Circulation. 78:II-535.

73. Izumo, S., B. Nadal-Ginard, and V. Mahdavi. 1988. Proto-oncogene induction and reprogramming of cardiac gene expression produced by pressure overload. Proc. Natl. Acad. Sci. USA. 85:339-343.

74. Schwartz, K., J.-L. Samuel, J.-J. Mercadier, A.-M. Lompre, C. Delcayre, D. de la Bastie, S. Schiaffino, and L. Rappaport. 1989. Contractile mechanisms of the normal and abnormal heart: study of molecular changes. In Cellular and Molecular Biology of Muscle Development. L. H. Kedes and F. E. Stockdale, editors. Alan R. Liss Co., New York.

75. Mayoux, E., Callens, F., B. Swynghedauw, and D. Charlemagne. 1988. Adaptational process of the cardiac $\mathrm{Ca}^{2+}$ channels to pressure overload: biochemical and physiological properties of the dihydropyridine receptors in normal and hypertrophied rat hearts. $J$. Cardiovasc. Pharmacol. 12:390-396.

76. Keung, E. C., R. Berg, and B. G. Katzung. 1987. Calcium current is increased in single myocytes from hypertrophied rat myocardium. Circulation. 76:II-329.

77. Trimmer, J. S., W. S. Agnew, S. A. Tomiko, S. M. Crean, Z. Sheng, R. Kallen, R. L. Barchi, S. S. Cooperman, R. H. Goodman, and G. Mandel. 1988. Isolation of cDNA clones encoding a developmentally regulated rat skeletal muscle sodium channel. J. Cell. Biol. 107:142a. (Abstr.)

78. Gu, Y., and Z. W. Hall. 1988. Immunological evidence for a change in subunits of the acetylcholine receptor in developing and denervated rat muscle. Neuron. 1:117-125. 